\title{
EVOLUTION OF THE NON-INITIAL VOCALIC LENGTH CONTRAST ACROSS THE FINNIC VARIETIES OF INGRIA AND ADJACENT AREAS
}

\begin{abstract}
The paper traces the evolutionary path of the non-initial vocalic length contrast in the Finnic varieties of Ingria and adjacent areas, from long vs. short vowels to short vs. no vowels. On the material from living varieties of the Ingrian, Votic, Finnish and Estonian languages, this sound change can be modeled very precisely, with statistical phonetic data analyzed for each stage of it. Among other things, the changes in various types of ratios between long and short vowels are described in more innovative varieties, as compared to Standard Finnish, which represents the most conservative stage. A special section describes a phonetic study on the reflexes of short vowels in Southern Lower Luga Ingrian, as well as in a mixed Siberian Ingrian/Finnish dialect. In these two varieties, vowel reduction, devoicing and elision occur at the most advanced level before the complete vowel loss. Also, a correlated study on phonemic categorization of these vowels by the native speakers is discussed. Both experiments indicate that in Southern Lower Luga Ingrian short vowel reflexes still retain the vocalic phonemic status, while in Siberian Ingrian/Finnish they should already be treated as consonantal features of palalization and labialiazation.
\end{abstract}

Keywords: Finnic varieties of Ingria, vowel reduction, auditory phonetics, phonology, sound change, phonemic categorization.

\section{Introduction}

Vowel reduction in the non-initial syllables is a widespread phenomenon in the Finnic languages. The degree of reduction varies considerably across varieties. One can observe a complete cycle of phonological sound change of the vocalic non-initial durational contrast in these languages. This cycle starts from a long vs. short vowel contrast and ends in a short vs. no vowel contrast. The paper describes this transformation in detail, elaborating how it transpires at each stage.

Finnic reduced vowels have emerged out of the non-initial short vowels in certain positions. The exact list of these positions slightly varies across the languages in question, but the main trends are very similar. The most widespread is apocope, followed by syncope. For example, in Lower Luga Ingrian reduced vowels typically occur foot-finally (examples are from InSLL): 


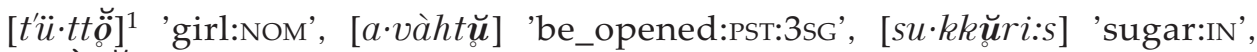
[li.sàेh ümi:nè] 'be_added:NMLZ:NOM' etc. Reduction is also possible foot-inter-

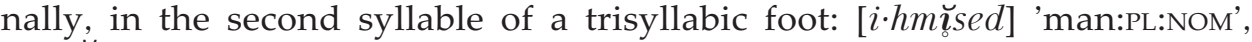

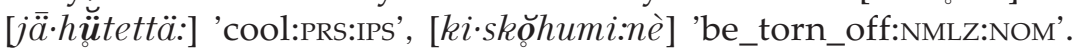

In the paper, the main focus will be on the Finnic languages of historical Ingria (currently the vicinity of St. Petersburg), where vowel reduction is a pronounced widespread process represented at many stages. All varieties of Ingria are subject to this reduction to some extent. Different varieties show how the original short vowels go through quantitative and qualitative reduction, grammatically and phonetically conditioned elision, and devoicing. Being further reduced, these segments subsequently turn into the consonantal features of palatalization and labialization, and are finally lost, while the original long non-initial vowels completely shorten.

The stages of reduction will be considered in the following varieties of Ingria: Ingrian Finnish (FiI; a part of South-Eastern Finnish dialects, see Kettunen 1930), the Soikkola (InS) and Lower Luga (InLL) dialects of the Ingrian language (Northern, Central and Southern varieties of Lower Luga Ingrian will be referred to as InNLL, InCLL, InSLL respectively), the Luutsa variety of the Western Votic dialect (VoL), and the mixed Siberian Ingrian/ Finnish variety of the Ryžkovo village (FiRyž). Comparative data on adjacent SouthEastern Finnish dialects of Karelia (FiSK), as well as on Standard Finnish (Fi) and Estonian (Es) will also be cited. Among all these varieties, special attention will be paid to those two that contain the complete phonological subsystems of reduced voiceless vowels, which are a typological rarity (Gordon 1998; Blevins 2004 : 199-201): Southern Lower Luga Ingrian and Siberian Ingrian/ Finnish. These varieties illustrate two successive stages of the evolution of reduced voiceless vowels (see sections $8-10$ ).

All Finnic varieties of Ingria are severely endangered. In 2006, there were several hundred Ingrian Finnish speakers scattered across Russia, Finland, Estonia and Sweden, 50-70 fluent Lower Luga Ingrian speakers and the same amount of Soikkola speakers, and less then 10 Western (Luutsa-Liivčülä and Jõgõperä) Votic speakers (Kuznetsova, Markus, Muslimov 2015); since then the number has decreased even more. As for the Siberian variety, in 2009-2012 there were some 30 fluent speakers (Сидоркевич 2013b : 11).

\section{The starting point of reduction: Standard Finnish}

In the paper, I will trace the development of reduction from the point when there was a distinct contrast of short and long vowels in the non-initial syllables. There is a general consensus in Finno-Ugric studies that this contrast does not go back to the Proto-Finnic stage, as there were no long non-initial vowels in Proto-Finnic. These vowels emerged in the process of the contraction of short vowels, while the consonants between the latter were lost (viz. e.g. Lehtonen 1970 : 136). Among all the Finnic languages, the situation in Standard Finnish is the closest to that point. In Standard Finnish, there is a robust opposition of short and long non-initial vowels.

${ }^{1}$ Hereafter, the devoicing of vowels is marked by the symbol [.] under the vowel, which corresponds to the capital letters traditionally used in FUT for voiceless vowels. Reduced vowels are marked with the symbol ["] over the vowel, which corresponds to the upside-down vowel symbols used for marking reduction in FUT. 
This contrast is foot structure insensitive and structurally unrestricted, it can occur in any syllable (see examples in Lehtonen 1970 : 29-30; Leskinen, Lehtonen 1985 : 49; Suomi, Meister, Ylitalo, Meister 2008 : 41). Two central types of contexts for this contrast analyzed hereafter include:

(1) position after a short syllable (open, containing a short vowel): kana 'hen:NOM' vs. kan $\bar{a}$ 'hen:PRT';

(2) position after a long syllable (all other syllable types): linna 'fortress:NOM' vs. linn $\bar{a}$ 'fortress:PRT'.

The phonetic distance between long and short non-initial vowels is very distinct (far over $2: 1$ ), and is even greater than the distance between long and short initial vowels (cf. the $\overline{\mathrm{V}}_{1} / \breve{\mathrm{V}}_{1}$ and $\overline{\mathrm{V}}_{2} / \breve{V}_{2}$ ratios for Standard Finnish, given in Table 1).

Foot isochrony, i.e. "interstress intervals [---] of approximately equal size" (Lehiste 1977), is observed in Standard Finnish in its embryonic phase. One of the important effects of foot isochrony in Finnic languages is that "a given sound is significantly shorter in a longer word than a corresponding sound in a shorter word" (Lehtonen 1970 : 143), and vice versa. This effect was generally not confirmed for Standard Finnish (Lehtonen 1970 : 143). The only robust effect was the realization of a short vowel in a syllable following the first short syllable as phonetically half-long: [kanà] 'hen:NOM' (the $\mathrm{V}_{2} / \mathrm{V}_{1}$ ratio in disyllables was 1.6 in Lehtonen's experiment, see Table 1). The duration of $\grave{V}_{2}$ in this shortest disyllabic foot structure (with the short first syllable) is thus phonetically prolonged to the maximum. This brings the overall foot duration closer to the duration of other foot types, which contain more segments. Absolute duration of this half-long vowel decreases in an inverse relation with increasing the number of syllables in a word (Lehtonen 1970 : 141-144). However, half-long vowel is not observed in all speakers of Standard Finnish: it depends on their dialectal background. Wiik and Lehiste, who have studied the matter, conclude on this isogloss (1968: 573-574): "In the type of Finnish that does not use a half-long vowel, quantity appears to function primarily on a segmental level. In dialects with the half-long vowel, quantity seems to have an additional higher-level function. In addition to manifesting the phonemic quantity of each vocalic segment, the duration of the vowels also contributes toward establishing the suprasegmental patterns characteristic of words."

There are solid grounds to reconstruct the phonetic tendency to foot isochrony (and the half-long vowel as one of its manifestations) already for Proto-Finnic. Foot isochrony was later disrupted in the process of vowel contraction, when phonemic long non-initial vowels emerged. However, this tendency was later restored in many Finnic varieties. In Standard Finnish, however, it was not restored: on the contrary, even the half-long vowel disappeared from some of its varieties (Lehtonen 1970 : 136-138; Prince 1980 : 545-546; Wiik 1991; Eek, Meister 2004 : 342-351). The area in which half-long vowels disappeared (see maps in Wiik 1975) highly overlaps with the area of Swedish historical settlements in Finland, and this might not be a coincidence.

In any case, we can consider the reduction stage observed in Standard Finnish as the most conservative in a sense that it is the closest to that particular proto-stage with disrupted foot isochrony and the robust contrast of non-initial short and long vowels. All the subsequent phases of the foot 
isochrony restoration and the vowel reduction will be traced in the article starting from this point. Standard Finnish length contrast of the non-initial vowels is schematized as follows (open disyllabic feet with initial short, see (1)-(2), and long, see (3)-(4), syllables are taken as examples):

(1) $[k a \cdot n a ̀ ~ \sim ~ k a \cdot n a]-(2)[k a \cdot n \bar{a}]$ ('hen' in SG:NOM Vs. SG:PRT);

(3) $[l i \cdot n n a]-(4)[l i \cdot n n \bar{a}]$ ('fortress' in SG:NOM Vs. SG:PRT; in the varieties of Ingria means 'city').

All the varieties analyzed below manifest further developments of this contrast. They will be considered according to their degree of innovation, in an order from the least to the most advanced. Varieties presented at a given stage include all the innovations from the previous stages.

\section{Restoration of the foot integrity in more innovative varieties}

Compared to Standard Finnish, all Finnic varieties of Ingria indicate more developed foot structure and stronger tendency towards foot isochrony (see e.g. Кузнецова 2009a : 34; Kuznetsova 2013; Markus 2010 : 48, 50 on Soikkola Ingrian). While Standard Finnish, in a sense, remained in that stage where foot integrity was disrupted by the emergence of long non-initial vowels, these latter varieties have overcome this disruption and have developed in the direction of restoring the foot integrity.

To demonstrate this, Table 1 summarizes the available experimental data on the average ratios of long or lengthened vs. short initial and non-initial vowels across disyllabic structures ${ }^{2}$ in the following Finnic varieties:

(1) Standard Finnish spoken by the speakers with various dialectal backgrounds;

(2) The South-Eastern Finnish dialects of South Karelia (the Karelian Isthmus and the southern coastal area of the Ladoga lake) and Ingria (Koprina, Skuoritsa and Tyrö parishes);

(3) Soikkola Ingrian;

(4) The Luutsa variety of Western Votic (more precisely, the Luu(di)tsa-

Liivčülä variety);

(5) Standard Estonian.

The varieties are organized from least to most innovative in terms of vowel reduction and the degree of development of the foot. Four types of ratios are represented:

(a) $\grave{V}_{2} / \breve{V}_{1}$ : second lengthened to first short vowel in disyllabic feet with a VCV nucleus; 3

(b) $\bar{V}_{2} / \grave{V}_{2}$ : phonemically long $2^{\text {nd }}$ syllable vowel after a long syllable (containing long vowel or diphthong and/or closed) to the lengthened second vowel in a VCV foot nucleus;

(c) $\bar{V}_{2} / \breve{V}_{2}$ : non-initial long to short vowels of the $2^{\text {nd }}$ syllable in other than VCV foot nuclei;

(d) $\bar{V}_{1} / \breve{V}_{1}$ : long to short vowels of the initial syllables in all foot nucleus types (first short vowel in the VCV nucleus included).

2 The durations of the long and short vowels in trisyllables are highly comparable with the data on disyllables. Not all the experiments cited in Table 1 provide data on trisyllables, therefore for the reasons of consistency we took only the disyllabic structures. 3 The sequence from the first throughout the second vowel in a $2-3$-syllabic foot is called 'foot nucleus' hereafter. 
The ratios are cited or calculated from various sources. The phrasal position of the words and the number of disyllabic structures, the presence or absence of a phrasal accent, as well as the size of samples, the number of speakers and the diversity of their geographic origin widely vary across experiments 4 (and are not provided in the table). The ratios, averaged across structures, phrasal positions, local subvarieties and the speakers of the respective experiments, vary much less and manifest several robust trends, listed below.

(1) Even in the Standard Finnish varieties with no half-long vowel, the second short vowel is slightly longer than the first one in a VCV nucleus (e.g. kana; the average $\grave{V}_{2} / \breve{V}_{1}$ ratio in a disyllabic foot was 1.1 in Wiik and Lehiste's experiment). In those Standard Finnish varieties that have halflong vowel, the $\grave{V}_{2} / \mathrm{V}_{1}$ ratio was $1.4-1.6$. In more innovative Finnic varieties, placed in the table to the right of Standard Finnish, this ratio is also around 1,6.

(2) On the other hand, the ratios between phonologically long and short vowels (both initial and non-initial, e.g. linna : linna a, karta 'tin:NOM' : kārto 'rainbow:NOM'5) in longer structural foot types dramatically shrink in other varieties, as compared to Standard Finnish. While in Standard Finnish these ratios $\left(\overline{\mathrm{V}}_{1} / \breve{\mathrm{V}}_{1}, \overline{\mathrm{V}}_{2} / \breve{\mathrm{V}}_{2}\right)$ are greater than $2: 1$, in all other varieties given in the table they are substantially smaller, especially for the non-initial vowels (both $\bar{V}_{1} / \breve{V}_{1}$, and $\bar{V}_{2} / \breve{V}_{2}$ ratios were mostly under $2: 1$, and $\bar{V}_{2} / \breve{V}_{2}$ ratios in all the experiments were under $1.7: 1){ }^{6}$

Therefore, we can observe the following dynamic tendency. The shortest foot nucleus structure $(\mathrm{C}) \operatorname{VCV}(\mathrm{C})$ phonetically extends the duration of a second etymologically short vowel. At the same time, longer foot nuclei shorten etymologically long vowels both in initial and non-initial syllables, bringing their duration closer to the duration of short vowels. These two processes lead to the strengthening of an overall foot isochrony.

(3) Longer $\grave{V}_{2}$ in VCV foot nucleus (kanà) and shorter $\bar{V}_{2}$ in other foot types (linna $\bar{a}$ etc.) result in a drastic change of their mutual ratio in all the varieties placed to the right of Standard Finnish, compared to the latter. In Standard Finnish, a half-long vowel in a VCV foot nucleus (kanà) can indeed be called half-long. It is longer by its absolute duration than other short vowels (linna), but shorter than phonologically long non-initial vowels

\footnotetext{
${ }^{4}$ I did not however include data on slow and fast speech tempos from Eek, Meister 2003 and 2004 (only on the moderate tempo), as well as the data on contrastively accented words from Suomi, Meister, Ylitalo, Meister 2013 (only on unaccented and accented words).

5 The last two examples are taken from InS.

6 The exception is the ratio of the Estonian first syllable long vowels in the third degree of quantity (Q3) to the initial short vowels. Estonian has a very innovative prosody compared to the Finnic languages of Ingria: it has developed a new suprasegmental foot-level opposition of three degrees of quantity (see e.g. Tauli 1953-1954; Lehiste 1960, and the subsequent extensive research). During this process, a phonological split in ratios has happened in the feet with the first long syllable, so a $2.4: 1$ ratio in Q3 is partly a secondary newly-acquired feature. Table 1 shows that the ratio in Q2 stays close to the Ingria-type ratios, while the ratio in Q3 resembles the Standard Finnish type. Proximity of Estonian Q3 ratios to the Finnish phonetic distance between long and short vowels has been mentioned in Eek, Meister $2004: 349$ and Meister, Meister 2013 : 241; in psycholinguistic experiment from Suomi, Meister, Ylitalo, Meister 2013 : 12 Finnish speakers confused words in their language rather with Estonian Q3 than with Q2.
} 
(linn $\bar{a}): \breve{\mathrm{V}}_{2}($ linna $)<\grave{\mathrm{V}}_{2}($ kanà $)<\overline{\mathrm{V}}_{2}$ (linn $\left.\bar{a}\right)$ (the average durations of these types of vowels in disyllables, counted across the experiments on Standard Finnish given in Table 1, were $59 \mathrm{~ms}, 107 \mathrm{~ms}$ and $130 \mathrm{~ms}$, respectively).

In more innovative varieties, the order of $\dot{V}_{2}$ and $\bar{V}_{2}$ reverses. It is now the $\grave{V}_{2}$ in VCV foot nucleus that becomes the longest non-initial vocalic type by its absolute duration: ${ }^{*} \breve{V}_{2}$ (linna) $<\overline{\mathrm{V}}_{2}$ (linn $\left.\bar{\alpha}\right)<\grave{\mathrm{V}}_{2}$ (kanà) (the average durations of these vowels, counted across the experiments on all the vari-

Table 1

Average ratios of long or lengthened (half-long) to short initial and non-initial vowels in several Finnic varieties

\begin{tabular}{|c|c|c|c|c|c|c|c|c|c|c|c|c|c|c|}
\hline \multirow[b]{2}{*}{$\begin{array}{l}\text { Types } \\
\text { of } \\
\text { ratios }\end{array}$} & \multicolumn{3}{|c|}{$\mathbf{F i}$} & \multicolumn{3}{|c|}{ FiSK } & FiI & \multicolumn{3}{|c|}{ InS } & \multicolumn{2}{|c|}{ VoL } & \multicolumn{2}{|c|}{ Es } \\
\hline & $\begin{array}{c}\mathrm{L} \\
1970\end{array}$ & $\begin{array}{c}\text { S } \\
\text { et al. } \\
2013\end{array}$ & $\begin{array}{l}\text { W\&L } \\
1968\end{array}$ & $\begin{array}{c}\text { L } \\
1978\end{array}$ & $\begin{array}{l}\text { L\&L } \\
1973\end{array}$ & $\begin{array}{l}\text { L\&L } \\
1985\end{array}$ & $\begin{array}{l}\text { K\&F } \\
2011\end{array}$ & $\begin{array}{c}\text { L } \\
1978\end{array}$ & $\begin{array}{c}K \\
2009\end{array}$ & $\underset{2011}{\text { M }}$ & $\begin{array}{l}\text { K\&F } \\
2013\end{array}$ & $\begin{array}{c}R \\
2015\end{array}$ & $\begin{array}{l}\text { E\&M } \\
2003\end{array}$ & $\begin{array}{l}\text { S } \\
\text { et al. } \\
2013\end{array}$ \\
\hline a) & & & & & & & & & & & & & & \\
\hline $\begin{array}{l}\mathrm{V}_{2} / \mathrm{V}_{1} \\
\text { (b) }\end{array}$ & 1.6 & 1.6 & $\begin{array}{ll}1.4^{1} & 1.1^{2}\end{array}$ & 1.6 & 1.6 & 1.5 & $-^{6}$ & 1.5 & 1.5 & 1.8 & - & 1.6 & 1.6 & 1.4 \\
\hline $\begin{array}{l}\overline{\mathrm{V}}_{2}, / \grave{\mathrm{V}}_{2} \\
\text { (c) }\end{array}$ & 1.3 & - & $1.4^{1} \quad 1.8^{2}$ & 0.8 & 0.9 & 0.9 & -6 & 0.8 & 0.7 & 0.8 & - & 0.8 & 0.7 & 0.7 \\
\hline $\begin{array}{l}\overline{\mathrm{V}}_{2} / \breve{\mathrm{V}}_{2} \\
\text { (d) }\end{array}$ & 2.8 & - & 2.3 & 1.7 & 1.7 & 1.7 & 1.5 & 1.5 & 1.6 & 1.3 & 1.3 & 1.6 & $1.4^{3}$ & $1.2^{3}$ \\
\hline$\overline{\mathrm{V}}_{1} / \breve{\mathrm{V}}_{1}$ & 2.1 & 2.1 & 2.3 & 1.6 & 1.7 & 1.6 & 1.3 & 1.8 & 1.6 & 1.9 & 1.5 & 2 & $\begin{array}{l}1.9^{4} \\
(\mathrm{Q} 2) \\
2,4^{5} \\
(\mathrm{Q} 3)\end{array}$ & $\begin{array}{c}2^{4} \\
(\mathrm{Q} 2) \\
2,4^{5} \\
(\mathrm{Q} 3)\end{array}$ \\
\hline
\end{tabular}

Abbreviations: (a) $\grave{\mathbf{V}}_{2} / \breve{V}_{1}-2^{\text {nd }}$ to $1^{\text {st }}$ vowel ratio in a (C) $\operatorname{VCV}(\mathrm{C})$ foot; (b) $\overline{\mathbf{V}}_{2}, / \grave{\mathbf{V}}_{2}-$ non-initial long vowels in feet with the first long syllable to the $2^{\text {nd }}$ vowel in a (C)VCV(C) foot; (c) $\overline{\mathbf{V}}_{2} / \mathbf{V}_{2}-$ non-initial long to short vowels in the feet with the first long syllable; (d) $\overline{\mathbf{V}}_{1} / \breve{V}_{1}-$ long to short vowels of the first syllable in all disyllabic foot types.

Notes: ${ }^{1}$ in varieties with a half-long vowel; ${ }^{2}$ in varieties with no half-long vowel; ${ }^{3}$ the ratio between the lengthened second vowel in Q2 words and the short second vowel in Q3 words; ${ }^{4} \overline{\mathrm{V}}_{1}$ from Q2 words; ${ }^{5} \overline{\mathrm{V}}_{1}$ from Q3 words; ${ }^{6}$ see however Leskinen, Lehtonen (1985 : 69), who note the existence of a half-long second vowel in the VCV foot nucleus also in Ingrian Finnish (which corresponds to my own auditory experience on these dialects), and claim that this type of lengthening in general is likely to originate from the South-Eastern corner of the Finnish language area.

Sources: L 1970 - Lehtonen 1970 : 127-129 (Standard Finnish of Jyväskylä); S et al. 2013 - Suomi, Meister, Ylitalo, Meister 2013 : 5 (Standard Finnish of Oulu, Standard Estonian of Tallinn); W\&L 1965 - Wiik, Lehiste 1968 : 571 (Standard Finnish against various dialectal backgrounds); K\&F 2011 - yet unpublished experiment conducted by Maxim Fedotov and myself in 2011-2012 on Finnish of Central and Western Ingria (see some results in Kuznetsova 2013); L\&L 1973 - Leskinen, Lehtonen 1973 : 320-324; L 1978 - Leskinen 1978 : 123-124, 127-128; L\&L 1985 Leskinen, Lehtonen 1985 : 53-55, 65, 68 (all three are on Finnish of South Karelia); L 1978 - Leskinen 1978 : 126, 129 (Soikkola Ingrian of Saarove); K 2009 - Кузнецова 2009a : 31, 35; M 2011 - Markus 2011 : 107-109, 114 (both are on Soikkola Ingrian of different villages); K\&F 2013 - yet unpublished experiment conducted by Maxim Fedotov and myself in 2013 on Luutsa and Jõgõperä Votic (see some results in Kuznetsova, Fedotov 2013); R 2015 - Rozhanskiy 2015 : 105-116 (Luutsa Votic; see also Rozhanskiy 2013); E\&M 2003 - Eek, Meister 2003 : 905; 2004 : 267, 269-270 (Standard Estonian). 
eties placed to the right of Standard Finnish in Table 1, were $77 \mathrm{~ms}, 114$ $\mathrm{ms}$, and $139 \mathrm{~ms}$, respectively). Therefore, it is no more correct to call $\mathrm{V}_{2}$ 'half-long' (or 'lengthened') and $\bar{V}_{2}$ 'long' for all these languages. Researchers studying the respective varieties have already expressed this concern, and those who aim at building synchronic structural descriptions prefer other phonetic and phonological labels (Leskinen, Lehtonen 1973 : 320; 1985 : 58, 66; Leskinen 1978 : 130; Кузнецова 2009b : 118; Markus 2011 : 109; Rozhanskiy 2015).

(4) In Finnish (both standard and dialectal), the ratios between long and short non-initial vowels (linna : linnā) are equal or greater than the ratios between initial long and short vowels (karta: kārto): $\overline{\mathrm{V}}_{2} / \breve{\mathrm{V}}_{2}>\overline{\mathrm{V}}_{1} / \breve{\mathrm{V}}_{1}$. In more prosodically innovative languages (Ingrian, Votic, Estonian), the ratios between long and short non-initial vowels become smaller than between the initial vowels: $\bar{V}_{2} / \breve{V}_{2}<\bar{V}_{1} / \breve{V}_{1}$. In Estonian, the most innovative of all the varieties in this respect, the difference between those ratios is especially big. ${ }^{7}$

This change in ratios provides an explicit example of how exactly the vowel reduction works in Finnic varieties. The phonetic distance between long and short vowels in the non-initial syllables has shrunk much faster than in the initial syllables. This process contributes to making the initial syllables much more prosodically prominent than the non-initial ones; it thus strengthens the metrical pattern typical for stress languages. It also creates premises for the ultimate disappearance of the length contrast in the non-initial syllables, where short vowels either merge with long ones in some positions or completely disappear in other positions (these two processes are considered in detail in sections 8-10).

Based on the data in Table 1, the schematic representation of the general change in ratios between long, lengthened (half-long), and short initial and non-initial vowels is given in Figure 1 and Table 2. Standard Finnish is taken as the first, more conservative stage. The situation in more innovative varieties, Finnish of South Karelia and Ingria, Soikkola Ingrian, Luutsa Votic and Standard Estonian, represents the second stage. In Figure 1, the relative phonetic distance between particular vowel types is symbolically depicted as their relative proximity to each other on the vertical scale. Between each pair of vocalic types, their average ratio is given (averaged across all the data from Table 1 on respective varieties).

For example, as the $\grave{V}_{2} / \breve{V}_{1}$ ratio in Standard Finnish is much smaller than both $\bar{V}_{2} / \breve{V}_{2}$ and $\bar{V}_{1} / \breve{V}_{1}$ ratios, the vertical distance between $\grave{V}_{2}$ and $\breve{V}_{1}$ is much shorter than between $\bar{V}_{2}$ and $\breve{V}_{2}$, and between $\bar{V}_{1}$ and $\breve{V}_{1}$. On the central picture of Figure 1, the dynamic process of change in phonetic distances is depicted. The $\bar{V}_{1} / \breve{V}_{1}$ and $\bar{V}_{2} / \breve{V}_{2}$ ratios are getting much smaller (the arrows are pointing inwards), while the $\hat{V}_{2} / \breve{V}_{1}$ ratio is getting slightly bigger (the arrows are pointing outwards). As a result, in more innovative varieties at Stage 2, all the three types of ratios get very close to each other.

\footnotetext{
${ }^{7}$ For Estonian, $\overline{\mathrm{V}}_{2} / \breve{\mathrm{V}}_{2}$ is the ratio between the lengthened second vowel in Q2 words and the short second vowel in Q3 words. This ratio is much smaller than the $\bar{V}_{1} / V_{1}$ ratios both in Q2 and in Q3 words (see Table 1).
} 
Table 2

Change in ratios between long, half-long and short initial and non-initial vowels across Finnic varieties of Ingria, as compared to Standard Finnish

\begin{tabular}{|c|c|c|}
\hline \multirow{2}{*}{$\begin{array}{l}\text { Stage } 1 \\
(\mathrm{Fi})\end{array}$} & & \multirow{2}{*}{$\begin{array}{l}\text { Stage } 2 \\
\text { (FiSK, FiI, InS, VoL, Es) }\end{array}$} \\
\hline & & \\
\hline$\overline{\mathrm{V}}_{2} / \grave{V}_{2}>1: 1$ & & $\mathrm{~V}_{2} / \grave{V}_{2}<1: 1$ \\
\hline$\overline{\mathrm{V}}_{2} / \breve{\mathrm{V}}_{2}>2: 1$ & $\rightarrow$ & $\overline{\mathrm{V}}_{2} / \breve{\mathrm{V}}_{2}<2: 1$ \\
\hline$\overline{\mathrm{V}}_{1} / \breve{\mathrm{V}}_{1}>2: 1$ & & $\overline{\mathrm{V}}_{1} / \breve{\mathrm{V}}_{1} \leq 2: 1$ \\
\hline
\end{tabular}

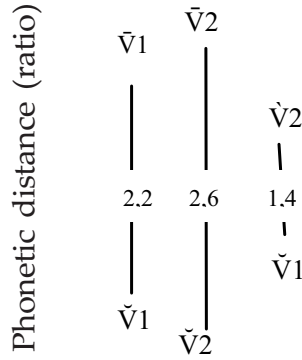

Stage 1

(Fi)

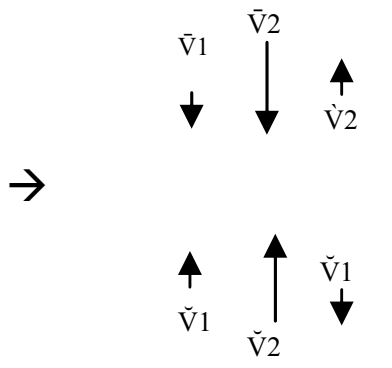

Change of ratios

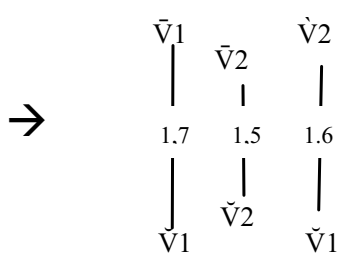

Stage 2

(FiSK, FiI, InS, VoL, and Q2 in Es)

Figure 1. Schematic representation of the evolution of ratios between long, halflong and short vowels.

\section{Positional restriction of the non-initial length contrast in more inno- vative varieties}

In the non-initial syllables, in addition to the drastic shrinking of ratios between long and short vowels, a morphonological restructurization of the vocalic length contrast has occurred in all the varieties placed in Table 1 to the right of Standard Finnish. This led to the restriction of positions possible for this contrast. The restructurization happened in two ways, but they both led to the same result for vocalic systems: the disappearance of the vocalic length contrast in the second syllable of the VCV foot nucleus.

The first, more archaic, path is observed in all the varieties of Ingria (apart for some Eastern Votic subdialects), as well as in a big part of Finnish dialects (basically the same that have the half-long second vowel in VCV foot nucleus, cf. Wiik 1975 : 420), also in South Estonian and Livonian (Palander 1987 : 10). The process is usually referred to as 'general secondary gemination' (yleisgeminaatio, in Finnish). The general rule is that during this process geminate consonants have emerged out of intervocalic singletons before the syllables that contained long vowels and diphthongs, e.g. *kanā 'hen:PRT' > [kannà] (FiI, InLL, partly VoL) / [kannà] (InS). As a result, the phonological contrast of long and short vowels in the second syllable of a VCV nucleus, as in Standard Finnish kana 'hen:NOM' vs. kanā 'hen:PRT', ceased to exist in these varieties. 
The second, more innovative, path of loss of this contrast is observed in some of those varieties where the general secondary gemination did not take place. Such gemination does not exist at all in Estonian and in Kattila Votic, and is irregularly present in those Votic varieties that have contacted with the Ingrian language (Viitso 1964). In Estonian and partly in Luutsa Votic (in the cases of absence of general secondary gemination, viz. Rozhanskiy 2015), original long second vowels in VCV foot nucleus merged with etymologically short (phonetically half-long) vowels. Therefore, in place of the Standard Finnish contrast kana vs. kanā ('hen' in NOM vs. PRT) only one variant is possible, be it phonetically [ka.nà] or $[k a \cdot n \bar{a}]$.

Positional restriction of the non-initial length contrast, compared to the stage represented in Standard Finnish, is schematized as following (innovations from the previous stage are marked in bold):

(1) $[k a \cdot n a ̀]>[k a \cdot n \grave{a} \sim k a n \overline{\boldsymbol{a}}]$ 'hen:NOM';

(2) $[k a \cdot n \bar{a}]>$ (a) $[k a \cdot \breve{n} \boldsymbol{n a ̀ , ~} k a \cdot n n \grave{a}]$ (FiSK, FiI, InS, InLL, some Votic varieties), or (b) $[k a \cdot n \grave{a} \sim k a \cdot n \overline{\boldsymbol{a}}]$ 'hen:PRT' (Es, some Votic varieties);

(3) $[$ li.nna $]=[$ li.nna $]$ 'city:NOM';

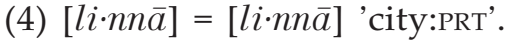

\section{Beginning of the qualitative vowel reduction and elision: Ingrian Finnish, Soikkola Ingrian}

Among living Finnic varieties of Ingria, Ingrian Finnish and Soikkola Ingrian manifest the first stages of vowel reduction, as compared to Standard Finnish. ${ }^{8}$ They differ from the Standard Finnish stage only by the features discussed in sections 3 and 4 . Other features characteristic of more advanced stages of reduction exist here at the initial level.

First, short non-initial vowels $a, \ddot{a}$ and sometimes $e$ tend to undergo qualitative reduction to schwa, ${ }^{9}$ especially in the fast speech (for Soikkola Ingrian, viz. Кузнецова 2009a : 33-34, 43; Markus 2011 : 117). In these varieties, such reduction can be still considered a phonetic phenomenon, as schwas are generally restored to the corresponding full vowels in well-articulated speech. However, there are already cases when, from the etymological point of view, a schwa is sometimes restored to full vowel incorrectly, e.g. [a.jjat] to ajjet, not to ajjat 'fence:PL:NOM' (Кузнецова 2009a : 33-34). In the transitional Soikkola to Lower Luga variety of Koskisenkülä, speakers sometimes pertain schwa instead of a full vowel even in well-articulated speech, cf. the syllabification of a word pikkarain 'small' by a speaker as [pi·k-kə·-ra·in] (Кузнецова 2012 : 101). Such varieties manifest the first stage of the formation of phonemic schwa.

Second, certain short non-initial vowels (especially $a, \ddot{a}$, more rarely $e$, $i, u, \ddot{u})$ undergo elision in certain contexts. For the varieties at this stage, the conditions are mostly grammatical. Regular vowel loss have occurred

\footnotetext{
8 In this paper, I do not consider those Ingrian Finnish and Eastern Votic varieties where non-initial long vowels were innovatively diphthongized (Ariste 1968:23; Муслимов 2009 : 191-194). Only reduction processes are analyzed.

9 The term schwa is used here for neutral central mid vowel [ə] (as in Iivonen, Sovijärvi, Aulanko 1990 : 36); see e.g. its formant structure in Votic in Rozhanskiy 2015 : 120, Table 23. In the languages discussed in this paper, schwa is not always an overshort vowel; especially reduced schwas will be separately marked as [ $\breve{a}$ ].
} 
in certain morphemes: some case suffixes (e.g. ${ }^{*}$-ssa/ss $\ddot{a}>-s$ IN, *-lla/-ll $\ddot{a}$ $\left.>-l \mathrm{AD},{ }^{*}-k s i>-k s \mathrm{TRL}\right)$, verbal declension suffixes (e.g. ${ }^{*}-n u t /-n \ddot{u} t>-n t$ PC:АСТ:РST), as well as some derivational suffixes, e.g. in the adjectival suffix $\left({ }^{*}\right.$-nen $\left.>\right){ }^{*}-n e>-n$ : *naine $>$ [nain ] 'woman:Nom'. In some cases, this grammatically conditioned process is still ongoing, as in plural partitive forms with the -oi-diphthong before a partitive suffix in the Southern Soikkola varieties: *astioja > [a.štioja a.štioi $]$ 'dish:PL:PRT'.

Only extremely rarely a phonetically conditioned phrasal elision occurs, when any vowel type can elide in the unstressed final position of any word in a sandhi with the following word, e.g. [paist] for paisti 'be_seen:PST:3sG' in ettäält $p$ a is $t$ ja '[It] could be seen from far away and [---]' (Laanest 1984 : 72; viz. also for other examples). I observed such elision also in the phrase-final position, e.g. [vet] for vettä 'water:PRT' in uhlulois on pal'ju $v e \bar{t}$ 'In the buckets, there is a lot of water'.

Vowel elision in the South-Eastern Finnish dialects (that include Ingrian Finnish) and in Soikkola Ingrian are considered in detail with numerous examples in Leskinen 1973 and Laanest 1980 and 1984. Obviously, grammatically conditioned vowel elision emerged earlier than purely phonetically conditioned elision (Laanest $1980: 73-74$ ), and it happened first of all in the most frequently used morphemes (Leskinen 1973 : 218). This is in line with the cross-linguistic studies showing that high-frequency grammatical elements tend to undergo sound change earlier and faster than low-frequency elements (Bybee 2001 : 11-12).

The innovations in Ingrian Finnish and Soikkola Ingrian, as compared to the Standard Finnish stage, are schematically represented below (innovations are in bold):

(1) $[k a \cdot n \grave{a}]>[k a \cdot n \grave{a} \sim k a \cdot n \overline{\boldsymbol{a}}]$ 'hen:NOM';

(2) $[k a \cdot n \bar{a}]>[k a \cdot \breve{n} n \grave{a} \mathrm{SI}, k a \cdot \boldsymbol{n n a ̀ ̀ ~} \mathrm{IF}]$ 'hen:PRT';

(3) $[$ li.nna $]>[$ li.nna $\sim$ li.nnə] 'city:NOM', but vowel loss under certain grammatical conditions (examples from $\mathrm{InS}$ ): (1) regular loss: *naine $>[\text { nainø }]^{10}$ 'woman:NOM' or (2) irregular loss: *astioja > [a·štioja a.štioin $]$ ] 'dishes:PL:PRT'; (4) $[l i \cdot n n \bar{a}]>[l i \cdot n n \grave{a}]$ 'city:PRT'.

\section{Regular phonetically conditioned vowel elision: Northern Lower Luga Ingrian}

The Lower Luga dialect differs the most from the other three Ingrian dialects, Soikkola, Hevaha ${ }^{\dagger}$ and Oredež ${ }^{\dagger}$. It has undergone heavy contact influence from the neighboring related languages of the Lower Luga area: Votic, Ingrian Finnish and, to some extent, Estonian (Лаанест 1966 : 146, 150-151; Муслимов 2005 : 5, 13). The reduction of non-initial vowels in Lower Luga Ingrian is the most salient of all the Ingrian dialects. Within this dialect, the degree of vowel reduction grows from the north to the south of the area (Кузнецова 2012). The Lower Luga subdialects range from the least to the most susceptible to reduction in the following way: Northern $>$ Central (comprising Eastern and Western) > Southern. For example, compare the variants of the word 'neighbor' in all these varieties (the names of the villages where a variant was registered in Ingrian speech are

$\overline{10}$ The sign $\varnothing$ marks the loss of vowel. 
given in parentheses; the most frequent variants for each group are in bold; for more examples see Кузнецова 2012 : 510-521):

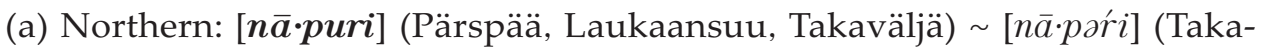
väljä);

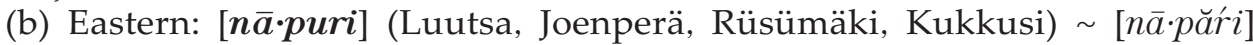

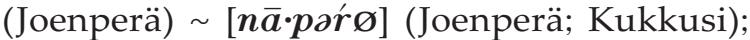

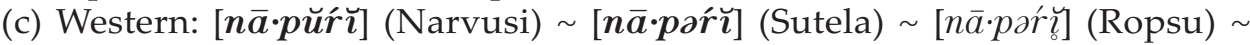

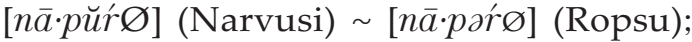

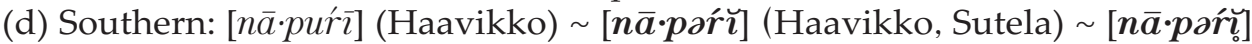

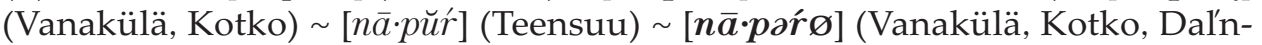

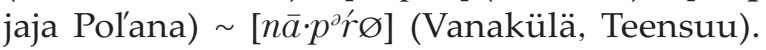

The level of reduction in Northern Lower Luga Ingrian is not much higher than in Ingrian Finnish or Soikkola Ingrian. All qualitative reduction of $a, \ddot{a}, e$ to schwa can be also considered phonetic here.

However, phrasal vowel elision in speech is not grammatically conditioned in this variety any longer. It is a very widespread and regular phenomenon conditioned only by phonetic rules. Elision happens both word-finally (apocope) and word-internally (syncope). Here are some examples from a speaker born in Pärspää:

(1) apocope:

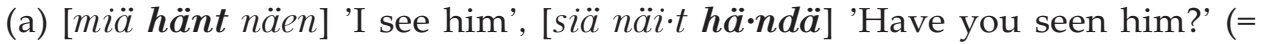
häntä 'he:PRT');

(b) $\left[\boldsymbol{p} \overline{\ddot{u}} h^{\prime} m \bar{a}\right]$ 'Sweep the floor' (= pü̈̈hi 'sweep:IMP:2sG');

(c) (while discussing the words for 'beautiful' in their language) [Mu·kàvo,

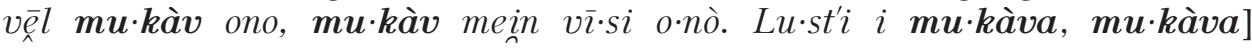
('Mukava, also there is mukava, our way is mukava. Lusti and mukava, mukava') (= mukava 'beautiful, nice');

(d) (while discussing the words for 'small' in their language) [I $p \bar{e} n, i$

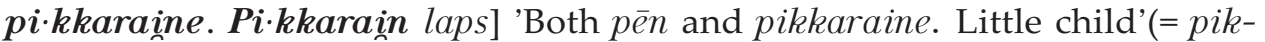
karaine 'small, little');

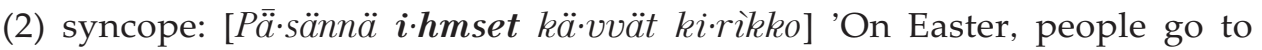
church' (= ihmiset 'human:PL:NOM').

Here, one can already speak about the structural positions of reduction, not about certain morphemes, as at the previous stage (cf. a detailed chart of these positions in Kuznetsova 2011 : 189; Кузнецова 2012 : 5960; also cf. examples in Section 1). Note that in Lower Luga Ingrian, reduction in frequently used grammatical morphemes is sometimes observed at more advanced stages than elsewhere (Кузнецова 2012 : 30-32). The likely reason is, as said in the previous section, that it has started there earlier.

The advance of vowel reduction in Northern Lower Luga Ingrian, as compared to the previous stage of Ingrian Finnish and Soikkola Ingrian, is schematically summed up below (innovations are in bold):

(1) $[$ ka $\cdot$ à $\sim$ kanā $]=[$ kanà $\sim$ kanā $]$ 'hen:NOM';

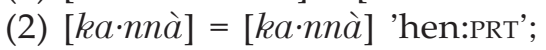

(3) [li.nna li.nnə] 'city:NOM', but grammatically conditioned elision in certain cases [na·ine nain] 'woman:NOM' > only structurally conditioned and unified rules of elision [li.nna $\sim$ li.nnə $\sim$ lin̄ø, na.inne $\sim$ nainnø];

(4) $[$ li.nnà $]=[$ li.nnà $]$ 'city:PRT'. 


\section{Development of the schwa phoneme and sporadic vowel devoicing: Central Lower Luga Ingrian, Luutsa Votic}

Central Lower Luga Ingrian represents the next stage of reduction. The same stage is manifest in the only still living variety of the Votic language, Luu(di)tsa Votic. These varieties are not far from the previous stage. The only important difference is that, in certain contexts, short non-initial $a, \ddot{a}$ and in some cases $e$ have completely reduced into the phonemic schwa:

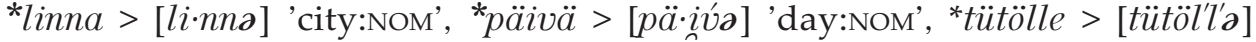
'girl:ALL' (see Viitso 1961; Кузнецова 2012; Rozhanskiy 2013; 2015). Measurements on Luutsa Votic show that the mean duration of schwa is shorter than of other reduced non-initial vowels in the same positions (Rozhanskiy 2015). Moreover, the speakers of Central Lower Luga Ingrian and Luutsa Votic are generally not aware of the presence of schwa in a word, though they often pronounce it, especially in the closed syllables, e.g. *lammaz > [łammaz] 'sheep:NOM'. The cases of speakers' non-perception of schwa for Kukkusi Votic (which was at the same stage of vowel reduction as Luutsa Votic) are given in Posti 1980 : XXI; for Lower Luga Ingrian, in Кузнецова 2009b : 164 and Kuznetsova 2012. For example, Posti's informants were writing words in their respective native varieties as пайкз

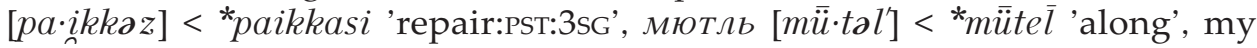
informants as турвз ог турваз [tu·rv z] < *turvas 'dung:Noм', лехм [le·h'ḿ̆ ]

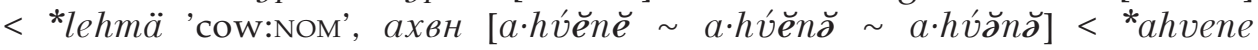
'perch:NOM'.

In Central Lower Luga Ingrian and Luutsa Votic, occasional phonetic devoicing of reduced vowels in certain positions is also attested; however, it is still very sporadic (Viitso $1961:$ 149, 151; 2008 : 201; Кузнецова 2012 : 84, 510-521). For example, [na·izikko] (VoL) 'woman:Nom' (Viitso 1961 :

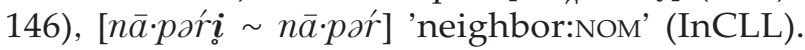

In addition, a considerable shortening of original long non-initial vowels is observed in both varieties. These vowels are often realized as short, i.e. there is a regular synchronic variation like [linnà $\sim$ linna] 'city:PRT/ILL' in speech. The length contrast in the non-initial syllables is thus being blurred (viz. Viitso 1961; 1981; Кузнецова 2012 : 41 -48; Kuznetsova, Fedotov 2013; Rozhanskiy 2015).

This reductional stage is compared to the previous one in the following scheme (innovations are in bold):

(1) $[$ ka.nà $\sim$ kanā $]=[$ kanà $\sim$ kanā $]$ 'hen:NOM';

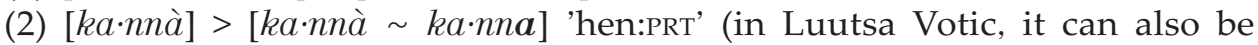
*kanā > [kanà $\sim$ kan $\overline{\boldsymbol{a}}])$;

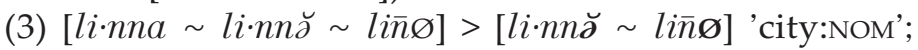

(4) $[$ linnà $]>[$ li.nnà $\sim$ li.nna $]$ 'city:PRT'.

\section{Well-formed phonological subsystem of reduced voiceless vowels: Southern Lower Luga Ingrian}

The southern subdialect of Lower Luga Ingrian is the most innovative of all the Finnic varieties currently situated in Ingria in respect of vowel reduction (on Siberian Ingrian/Finnish, which is not geographically placed in 
Ingria, see section 9). It is immediately adjacent to the area of the even more innovative Estonian language. The devoicing and elision of the non-initial reduced vowels and some diphthongs in rapid speech are extremely frequent here, e.g. [tahtovăd tahtŏvad tahtøvəd] < *tahtoivad 'want:PST:3PL' (see also examples in Section 1 and in Кузнецова 2012 : 516-521).

The original long non-initial vowels have completely shortened here, so the only lengthened non-initial vocalic type is the second half-long vowel in a foot with VCV nucleus. This half-long vowel is considered an allophone of a short non-initial vowel, as it does not form a phonological contrast with the latter.

In the non-initial syllables, the subsystem of reduced voiceless vowels is thus phonologically contrasted to the short modal vowels, e.g. $/ \breve{1} /$ in $[t \bar{u} l \overline{\boldsymbol{\imath}}]$ 'wind:NOM' $\left(<{ }^{*} t \bar{u} l i\right)$ vs. /i/ in [tuli] 'fire:NOM' $\left(<{ }^{*} t u l i\right)$ and [süt'i $]$ 'judge:PRs:3sG' $\left(<{ }^{*} s \bar{u} t \bar{\imath}\right)$. This subsystem has preserved all the original qualitative contrasts of the system it had emerged from, with the exception of the height contrast for middle vowels: [ $\left.\ddot{*},{ }^{*} \ddot{o},{ }^{*} u,{ }^{*},{ }^{*} i,{ }^{*} e,{ }^{*} a,{ }^{*} \ddot{a}\right]>[\breve{u}$, $\breve{o}, \breve{u}, \breve{o}, \breve{\imath}, \breve{e}, \breve{\partial}\left(<^{*} a,{ }^{*} \ddot{a}\right.$, partly $\left.\left.{ }^{*} e\right)\right]$. More data on Southern Lower Luga Ingrian reduced voiceless vowels can be found in Mägiste 1925; Ariste 1965; Кузнецова 2012 and Kuznetsova 2015.

However, a tendency towards the merger of etymological high and nonhigh vowels is already observed here: $\breve{u}$ with $\breve{o}$; $\ddot{u}$ with $\ddot{o}$; $\breve{e}$ both with $ə(<$ $\ddot{a})$ and $\breve{l}$. For example, speakers transcribe [aukkŏ] 'hole:NOM' as aukko or aukku (cf. Кузнецова 2012 : 23; Kuznetsova 2012). Also, Mägiste mentions in his early research the "darkening" of the voiceless $o, e, \ddot{o}$ : "Sometimes it is hard to distinguish these darkened sounds from the close $u, i$, $\dddot{u}$ " (1925 : 80).

As argued in Kuznetsova 2015, reduced voiceless vowels are to be treated as phonologically reduced rather than voiceless, i.e. / $\breve{u}, \breve{o}, \breve{u}, \breve{o}, \breve{1}, \breve{e}$, ə/. The reduced schwa phoneme also occurs in the positions where it cannot elide due to phonotactic and speech production restrictions, e.g. [łammə̆z] 'sheep:NOM'. In such cases, schwa is pronounced as a reduced but not a voiceless vowel.

Additionally, as an experiment in the present paper suggests (see Figure 2), the devoiced allophones are only the third frequent type of realization, after modal vowels and complete vowel loss. Therefore, the reduced character of vowels should be considered the primary phonetic feature which sometimes triggers devoicing in some, but not all, contexts. In this sense, the case of Ingrian reduced voiceless vowels does not stand out of other cross-linguistically known similar cases. It seems that voicelessness is in no language a primary underlying feature that would be completely independent of other vocalic features and/or of immediate phonetic context (Kuznetsova 2015).

The schematic representation of this stage of reduction, as compared to the previous one, is given below (innovations are in bold):

(1) $[$ ka $\cdot$ à $\sim$ kanā $]=[$ kanà $\sim$ kanā $]$ 'hen:NOM';

(2) $[$ kannà kanna $]>[$ kanna $]$ 'hen:PRT';

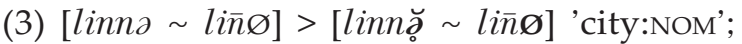

(4) $[$ linnà linna $]>[$ linna $]$ 'city:PRT'. 


\section{The consonantal features of palatalization and labialization: Siberian Ingrian/Finnish}

Siberian Ingrian/Finnish is a mixed variety of Southern Lower Luga Ingrian and the Ingrian Finnish variety of the Lower Luga area. Since the works by Zlobina (Злобина 1971; Zlobina 1972) and Nirvi (1972), this ethnic group has been known by the name korlaki. However, a sociolinguistic research conducted by Sidorkevič has found that this nomination is thought pejorative by the speakers and is rather to be avoided (Сидоркевич 2012).

This dialect also originates from Ingria. It is spoken by an ethnic group whose ancestors were expelled to the Omsk region of Western Siberia in 1803-1804 after an upspring against Baron von Ungern-Sternberg. They settled down in the village of Ryžkovo and the surrounding ones. The speakers originated from the Rosona river basin, where Southern Lower Luga Ingrian has been traditionally spoken along with the local Ingrian Finnish dialects. The Siberian variety has existed in complete isolation from its 'mother' languages for more than two centuries. It has however been in some contact with local Siberian Estonian (Сидоркевич 2012).

Apart from the early works mentioned above, the Siberian variety remained completely unstudied until very recently. This partly happened because this group has changed their ethnic identity into Estonian, and was thus sociologically indistinguishable from Siberian Estonians residing in the same area (Сидоркевич 2012). Recently, a comprehensive field study on the Siberian variety has been conducted by Sidorkevič (Сидоркевич 2013b). Among other things, she has also discovered the traces of reduced voiceless vowels in this dialect (viz. Sidorkevich 2011 : 577; Сидоркевич 2013a).

In Siberian Ingrian/Finnish, reduced vowels have completely lost the original height contrast. The system now contains two binary oppositions, in backness and labialization: $\left[\breve{u}, \breve{\jmath}, \breve{g}\left(<{ }^{*} a,{ }^{*} \ddot{a},{ }^{*} e\right), \breve{\theta}^{11}\left(<{ }^{*} u,{ }^{*} O,{ }^{*} \ddot{O}\right)\right]$. This system can be already described through the consonantal features of palatalization and labialization (C stands for any consonant): [C' $\left.\mathrm{C}_{\breve{Q}}\right]=/ \mathrm{C}^{\prime \circ}, \mathrm{C}^{\prime}, \mathrm{C}, \mathrm{C}^{\circ} /{ }^{12} \mathrm{Such}$ an interpretation is even preferable for this variety, at least according to the phonetic realization and the speakers' introspection (see section 10).

Interpretation of voiceless vowels through the consonantal features leaves the Siberian variety with an ample transitory system of consonants. The majority of consonants come to have four variants: plain, palatalized, labialized and labialized palatalized. For example, /kät/ (< *kättä 'hand:PRT') vs. /hunt'/

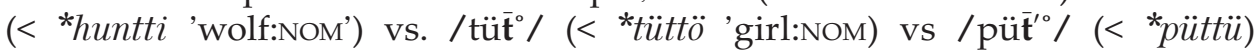
'barrel:NOM'. Many of these consonants are marginal and have a vague phonological status. Their positions of occurrence are extremely restricted, and palatalization and especially labialization are not coherent in realization for the majority of the consonantal groups.

The development of reduction in this variety, as compared to the previous stage, is summed up in the scheme below (a word püttü 'barrel:NOM' containing a front labial final vowel was added for more representativeness; innovations are in bold):

$\overline{11}$ Labialized central midvowel (see Iivonen, Sovijärvi, Aulanko 1990 : 36).

12 Consonantal labialization is marked with the symbol [ $\left.{ }^{\circ}\right]$ after the consonant. 
(1) $[k a \cdot n a ̀ ~ \sim ~ k a \cdot n \bar{a}]=[k a \cdot n a ̀ ~ \sim ~ k a \cdot n \bar{a}]$ 'hen:NOM';

(2) $[k a \cdot n n a]=[k a \cdot n n a]$ 'hen:PRT';

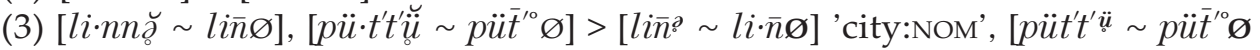
pü̈t'ø] 'barrel:NOM';

(4) $[$ li.nna $]=[$ li.nna $]$ 'city:PRT'.

In the following section, some comparative data from the pilot phonetic experiment on the production of reduced voiceless vowels in Southern Lower Luga Ingrian and Siberian Ingrian/Finnish are given. In addition, a comparative experiment shedding light on how speakers of these two varieties themselves categorize the vowels in question is described.

\section{Experimental study on the production and categorization of reduced vowels in Southern Lower Luga Ingrian and Siberian Ingrian Finnish}

\subsection{The phonetic experiment}

In 2013 - 2014, I conducted a pilot phonetic study on reduced voiceless vowels in one idiolect of Southern Lower Luga Ingrian and one idiolect of Siberian Ingrian/Finnish. Lower Luga Ingrian speaker AMŠ (female, born in 1932) originates from the village of Dal'naja Polana on the right bank of the Luga river. In summer, she resides in her native village, and in winter, in the mostly Russian-speaking town of Narva in Estonia. Siberian Ingrian/Finnish speaker PMŠ (female, born in 1950) comes from the Ryžkovo village, and lives there in summer, while staying in the Estonian capital of Tallinn for winter. Both speakers have a good command on spoken and written Russian. During winter season, they both are exposed to some spoken and written Estonian and can passively understand it to some extent, but do not speak it actively.

The questionnaire was the same for the two varieties and contained simple carrier phrases, where 46 target lexemes occurred both in the phrase-initial and the phrase-final position. Target lexemes were nouns, 41 disyllables and 5 trisyllables, in two forms: the nominative and the illative (in some cases illative/partitive). These forms constituted minimal pairs opposed only by the length of the final vowel, reduced vs. short, e.g. [hu·st' $\mathbf{\imath}]$ 'beautiful:NOM' $(<*$ lusti) vs. [łu·st'i] 'beautiful:ILL' (< *lustī), [pa.pèrî̀] 'paper:NOM' (< *paperi) vs. [pa·pèri] 'paper:ILL' $(<$ *paper $\bar{\imath})$. The questionnaire contained words ending in vowels of all types, except for $\ddot{o}$ and $e$, after various types of consonants $(t, k, l, m$, $r, n, v, j, h)$. In total, it represented a diverse range of combinations of particular vowels and consonants in the final syllable. The whole questionnaire contained 184 phrases; each was supposed to be pronounced at least twice.

In the production of reduced vowels, I studied the following types of realizations: (1) modal vowel; (2) voiceless vowel (partially or completely devoiced); (3) consonantal palatalization or labialization, or both, without a vowel; (4) complete vowel loss without any traces left. The major results will be summarized below.

\subsection{Mean durations of long and short non-initial vowels in open disyllables}

Table 3 presents the data on the mean durations of short $\left(<{ }^{*}\right.$ long $)$ and reduced ( $<{ }^{*}$ short) vowels in Southern Lower Luga Ingrian (InSLL) and Siberian Ingrian/Finnish (FiRyž). The mean durations of reduced vowels 
were calculated based on the pronunciations with no vowel loss. Disyllabic and trisyllabic structures are given separately. However, the data on trisyllables are very scarce; and the means that were calculated on the basis of less than 5 tokens are given in parentheses. The ratios of etymological long to short vowels were calculated only for disyllabic structures.

Table 3

Mean durations and the ratios of short $\left(<{ }^{*}\right.$ long) and reduced $\left(<{ }^{*}\right.$ short $)$ non-initial vowels in InSLL and FiRyž

\begin{tabular}{|c|c|c|c|c|c|c|c|c|c|}
\hline & \multicolumn{4}{|c|}{ InSLL } & \multicolumn{4}{|c|}{ FiRyž } \\
\hline & & \multicolumn{2}{|c|}{$\begin{array}{l}\text { Phrase-initial } \\
\text { position }\end{array}$} & \multicolumn{2}{|c|}{$\begin{array}{l}\text { Phrase-final } \\
\text { position }\end{array}$} & \multicolumn{2}{|c|}{$\begin{array}{l}\text { Phrase-initial } \\
\text { position }\end{array}$} & \multicolumn{2}{|c|}{$\begin{array}{l}\text { Phrase-final } \\
\text { position }\end{array}$} \\
\hline & & $\overline{\mathrm{x}}, \mathrm{ms}$ & $\mathrm{n}$ & $\overline{\mathrm{x}}, \mathrm{ms}$ & $\mathrm{n}$ & $\overline{\mathrm{x}}, \mathrm{ms}$ & $\mathrm{n}$ & $\overline{\mathrm{x}}, \mathrm{ms}$ & $\mathrm{n}$ \\
\hline \multirow{2}{*}{$\begin{array}{l}\text { NOM } \\
\left({ }^{*} V_{2}\right)\end{array}$} & 2-syllabic & 66 & 78 & 70 & 89 & 60 & 17 & 84 & 54 \\
\hline & 3-syllabic & (69) & (3) & (87) & (3) & - & 0 & (107) & (1) \\
\hline \multirow{2}{*}{$\begin{array}{l}\text { ILL/PRT } \\
\left({ }^{*} \bar{V}_{2}\right)\end{array}$} & 2-syllabic & 96 & 87 & 120 & 96 & 118 & 77 & 138 & 83 \\
\hline & 3-syllabic & 85 & 12 & 121 & 11 & 127 & 6 & 140 & 11 \\
\hline${ }^{*} \overline{\mathrm{V}}_{2} /{ }^{*} \breve{\mathrm{V}}_{2}$ & $\begin{array}{l}\text { 2-syllabic } \\
\text { Across } \\
\text { positions }\end{array}$ & \multicolumn{4}{|c|}{1.6} & \multicolumn{4}{|c|}{1.8} \\
\hline
\end{tabular}

The $* \overline{\mathrm{V}}_{2} /{ }^{*} \breve{\mathrm{V}}_{2}$ ratio in the InSLL idiolect fits within the range of the ratios found in other Finnic varieties of Ingria (see Table 1). In the FiRyž idiolect, the $1,8: 1$ ratio suggests that etymological long vowels have not yet completely lost their lengthening, at least in the open final syllables. Mean durations indicate that etymological short vowels are reduced both in InSLL and in FiRyž. However, as for the etymological long vowels, the mean values suggest that the latter have completely shortened in InSLL, while still phonetically retain the lengthening in FiRyž (those are though the data on just one idiolect per variety).

Phonologically, I treat the contrast in InSLL as / reduced/ vs. /short/ vowels (Кузнецова 2012; Kuznetsova 2015). In FiRyž, the reflexes of etymological short vowels in the positions of the vowel loss are considered consonantal features of labialization and palatalization (see further discussion below). Etymological long vowels are considered phonologically short, the same way as in Сидоркевич 2013a; 2013b. Such view is also corroborated by my preliminary findings from the phonetic research on FiRyž non-initial vowels in closed disyllables. In this position, where vowel loss is not possible, original long and short vowels seem not to be contrasted any longer, e.g.: suolat means now both *suolat 'salt:PL:NOM' and *suolaat 'salt:PRs:2sG'; krāmit 'trash:PL:NOM' $\left(<{ }^{*} k r \bar{a} m i t\right)$ has the same second vowel as rümit 'body:PL:NOM' $\left(<{ }^{*} r \bar{u} m \bar{\imath} t\right)$ etc. (exact phonetic measurements are however yet to be conducted).

In the following discussion, I will further consider only the results on the etymological short vowels.

\subsection{Vowel devoicing and loss}

The two parameters by which InSLL and FiRyž differed very significantly were the rates of devoicing and loss of reduced vowels. Figures 2 and 3 present the results for vowel devoicing and loss in the two phrasal posi- 
tions studied. The samples compared were completely balanced across the two positions for the same informant. They contained the same number of identical or, in some rare cases, maximally comparable tokens. The samples across the informants were slightly unbalanced (for InSLL, $n=126$ in each position; for FiRyž, $\mathrm{n}=140$ ), though only about $10 \%$ of tokens did not coincide. Therefore, the results across informants are highly comparable. In Figure 2, voiced (modal) and voiceless vowels are given separately, while in Figure 4, they are united in the same category of 'no V loss', as opposed to 'V loss'.

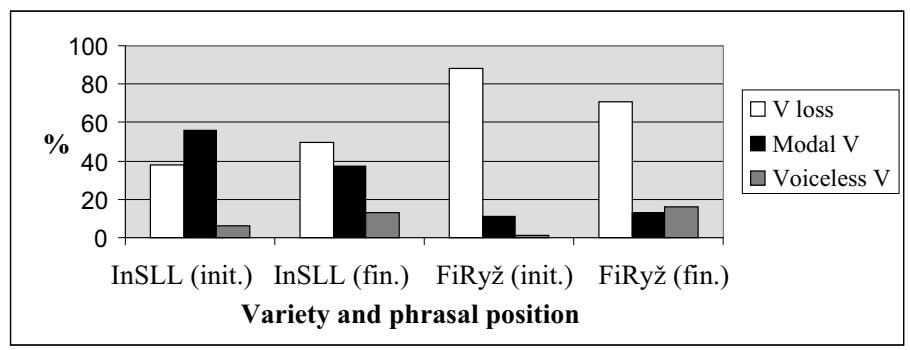

Figure 2. The percentage of modal vowels, vowel devoicing and loss in InSLL and FiRyž in the phrase-initial ('init.') and phrase-final ('fin.') position.

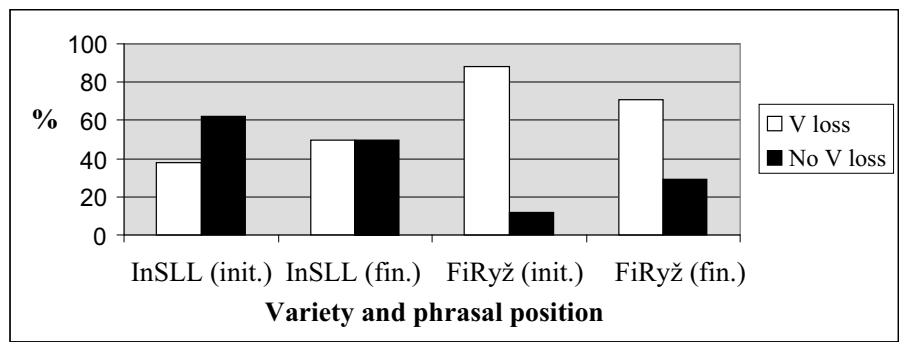

Figure 3. The percentage of vowel loss vs. no loss in InSLL and FiRyž in the phrase-initial ('init.') and -final ('fin.') positions.

The main conclusions from Figures 2 and 3 can be summarized as follows: (1) A drastic increase of the overall vowel loss is observed in FiRyž, as compared to InSLL. In InSLL, vowel loss is equally or even less frequent than vowel retaining, while in FiRyž, vowel loss overwhelmingly prevails (it makes for $70-90 \%$ of all pronunciations). This shift is crucial and of qualitative nature, as it changes the most frequent type of realization (the category prototype, in terms of Rosch 1978).

(2) In line with the previous, vowel devoicing is more widespread in FiRyž, in comparison to InSLL. As expected, ${ }^{13}$ in both varieties the vowel devoicing is more common in the phrase-final position, where the energy put into pronunciation falls. In the phrase-final position, the difference in devoicing rates between InSLL and FiRyž is, again, qualitative and significant. While in InSLL, voiced allophones overwhelmingly prevail over the voiceless ones in this position (they make about $2 / 3$ of all vocalic realizations),

13 Blevins (2004: 199), who has studied the main trends in evolution of voiceless vowels cross-linguistically, notes that vowel devoicing typically occurs phrase- or word-finally. Also, Lehtonen $(1970: 45)$ mentions the phonetic voicelessness of the 'tail' of a whole utterance as a 'common feature in spoken Finnish'. 
in FiRyž, voiceless allophones already become more common phrase-finally than the voiced ones (slightly more than the half of all vocalic realizations).

\subsection{Phonemic categorization by the speakers}

In addition to the phonetic measurements, I ran a test on how the same two speakers categorize the final reduced vowel in the target words (in the nominative) from the phonetic questionnaire. Neither the Ingrian language, nor the Siberian Ingrian/Finnish has any standard written variety. There was an attempt to create literacy in Ingrian in the beginning of the 1930s, but it was swiftly put to an end by the change in Stalin's linguistic policy in 1938-1939 (Kuznetsova, Markus, Muslimov 2015). Therefore, if speakers of these varieties are asked to write in their native languages, they do it just the way they intuitively feel, as no orthographic norms interfere. My aim was to check whether AMŠ and PMŠ would write any final vowel in those words which they had pronounced in the phonetic experiment, or not. The speakers were free to write in either Cyrillic or Latin letters. Figure 4 presents the results of the categorization study.

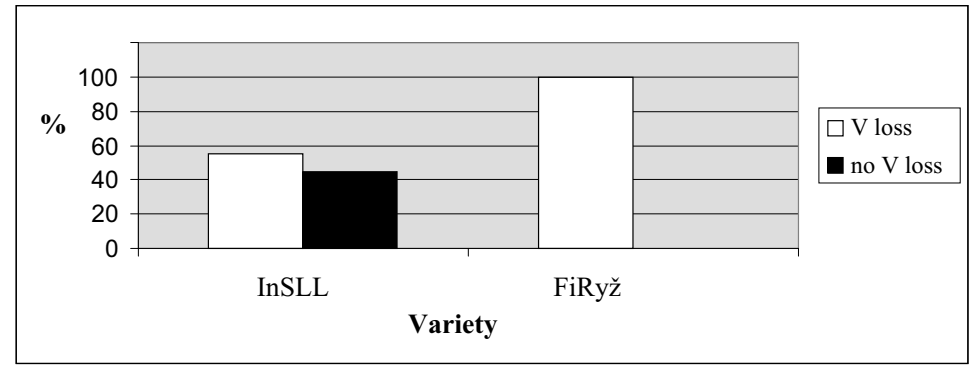

Figure 4. The percentage of orthographic vowel loss in InSLL and FiRyž in the target nominative forms from the phonetic questionnaire.

The results of the perception experiment strongly correlate with the production study.

(1) In InSLL, orthographic vowel loss happens in slightly more than the half of cases. In terms of Rosch (1978), not just in production, but also in the cognitive mental representation of the speaker, 'vowel' and 'no vowel' are obviously two robust category prototypes. In some cases, AMŠ explicitly stated that a word can be pronounced both with and without vowel, and correspondingly gave two orthographic variants.

It is worth notice, that in her production the vocalic variants were more frequent than the non-vocalic ones (especially in the phrase-initial position), while in the categorization experiment non-vocalic variants already slightly prevailed. Phonemic categorization thus seems, in a sense, more innovative than phonetic production. This is in line with the hypothesis expressed within the usage-based paradigm, that phonemic reanalysis happens at the early stage of sound change: "This process of reanalysis can occur very early in the development of a phonological change. [---] Restructuring is covert the speakers change their analysis before the surface forms of the language change (Andersen 1973)" (Bybee 2001 : 55; the same idea was also expressed by Попов 2004 : 76-77; Касаткин 1999 : 96). 
(2) The same innovative character of categorization, as compared to production, is also observed in the data from PMŠ. In writing, she wanted to put a final vowel in no case. The phonemic representation in her mind obviously contains just one prototype ('no vowel'). Vowel loss in respective positions is thus cognitively complete in her idiolect. The same observation on the non-vocalic phonemic categorization by FiRyž speakers was made by Sidorkevič, who interviewed more than one speaker on the matter (Сидоркевич 2013a : 680-681). At the same time, Sidorkevič also mentions that FiRyž speakers do not perceive, for example, words [ku $\left.\bar{k}^{\circ}\right]$ 'rooster:NOM' $\left(<^{*} k u k k o\right)$ and $\left[k u \bar{k}^{2}\right]$ 'flower:NOM' (<*kukka) as identical. Speakers often spontaneously cited these exemplificative words as non-homonymic in their language (Сидоркевич 2013a : 680-681). This fact indicates that the traces of reduced voiceless vowels are still preserved in speakers' phonemic categorization and can distinguish minimal pairs. At the same time, vowel reflexes have already indeed phonologically transformed into the consonantal features of labialization and palatalization. Speakers themselves pointed out that it is a different kind of a final consonant (and not different vowels) that opposes such pairs (Сидоркевич 2013a : 680-681).

\section{The utmost loss of reduced voiceless vowels: Standard Estonian}

As mentioned previously (see section 9), Siberian Ingrian Finnish has an ample consontantal inventory, with a very large marginal periphery. Sidorkevič mentions that the stability of realization of labialization and palatalization varies a lot among consonantal types, frequent vs. infrequent words and the particular vocalic types that gave rise to these features. She suggests that such instability indicates the tendency towards the simplification of the system (Сидоркевич 2013a : 676, 679-680).

This hypothesis is corroborated by the subsequent stage of evolution observed in Estonian. In Standard Estonian, the original short vowels were completely lost in roughly the same positions where InSLL and FiRyž have reduced voiceless vowels or their remnants. Estonian has obviously also passed through the stage of voiceless vowels before their ultimate loss (see data on the Estonian dialects which still maintain reduced voiceless vowels in Tauli $1956:$ 66-84).

In Estonian, no traces of consonantal labialization remained, e.g. pütt [püt'] 'tub:NOM' (< *püttü). Palatalization was preserved, though only for some dental consonants. Palatalization is not marked in Estonian orthography, and there has been no normalization in the use of palatalized phonemes, which varies a lot across Estonian speakers with different dialectal backgrounds (Laugaste 1956 : 81). The majority of regional varieties contain four types of palatalized consonants: $t, n, s, l$. Palatalization of $r$ sounds old-fashioned in contemporary Standard Estonian (Ariste 1953 : 80; Hint 1998 : 154), though was wide-spread in the Central North Estonian dialect, which had laid a basis for the standard language (Must, Univere 2002 : 100). Only very seldom can also $k$ and $\eta$ be palatalized in this dialect (Laugaste $1956: 74$, 76; Must, Univere 2002 : 98). Table 4 summarizes the consonantal inventory of Standard Estonian. In addition, the palatalized consonants that are not present in the contemporary standard variety, but occurred in the Central North Estonian dialect are added. 
Consonantal inventory of Standard Estonian with some data from the Central North Estonian dialect

\begin{tabular}{|c|c|c|c|}
\hline Labial & Dental & Palatal & Velar \\
\hline$p \bar{p}$ & $t \bar{t} \boldsymbol{t}^{\prime} \overline{\boldsymbol{t}}^{\prime}$ & & $k \bar{k}(\boldsymbol{k} \overline{\boldsymbol{k}} \mathrm{EsCN})$ \\
\hline$m \bar{m}$ & $n \bar{n} \boldsymbol{n} \overline{\boldsymbol{n}}$ & & $(\eta)(\eta \operatorname{EsCN})$ \\
\hline$f \bar{f}$ & $S \bar{s} s^{\prime} \bar{s}$ & & $h \bar{h}$ \\
\hline$v \bar{v}$ & $\check{S} \bar{S}$ & & \\
\hline & $l \bar{l} \boldsymbol{l}^{\prime} \overline{\boldsymbol{l}}^{\prime}$ & & \\
\hline & $r \bar{r}(\dot{r} \bar{r} \mathrm{EsCN})$ & & \\
\hline$(w \bar{w})$ & \multicolumn{3}{|c|}{$j \bar{\jmath}$} \\
\hline
\end{tabular}

Palatalization, therefore, proves to be a more stable feature than labialization. However, there is a dynamic tendency in Estonian towards the disappearance of particular palatalized consonants from the system in general (as it happened with $\dot{r}$ ), as well as from certain phonetic contexts and structural types of words (Teras, Pajusalu 2014). Estonian palatalization is in fact prepalalization, and its degree of prominence varies a lot as a function of a consonantal type, its geminate or singleton nature, the surrounding phonetic context, the degree of quantity in a foot, particular segmental structure of a word, and the age of speakers (Laugaste 1956; Eek 1971; 1973; Hint 1998; Must, Univere 2002; Teras, Pajusalu 2014). Operstein (2010) observes that prepalatalization is often a part of the process of consonantal depalatalization.

The final stage of evolution of the non-initial vocalic length contrast, as indicated from Standard Estonian, is summarized below (innovations in comparison with the previous stage are in bold):

(1) $[k a \cdot n a ̀ ~ \sim ~ k a \cdot n \bar{a}]=k a n a[k a \cdot n a ̀ ~ \sim ~ k a \cdot n \bar{a}]$ 'hen:NOM';

(2) [ka.nna] for 'hen:PRT' is not present in Standard Estonian, there is kana $[k a \cdot n \grave{a} \sim k a \cdot n \bar{a}]$ instead, cf. section 4;

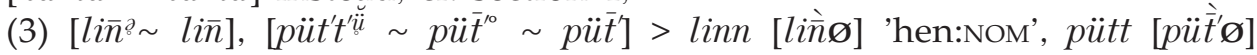
'tub:NOM'; 14

(4) $[l i \cdot n n a]>$ linna $[l i \cdot \grave{n} n a]$ 'city:PRT' (the development of prosodic Q3 in PRT/ILL, but no principal innovations in terms of the final vowels).

12. Conclusion: a model for the evolutionary chain of the Finnic noninitial vocalic length contrast

Three types of sound change processes in the Finnic varieties of Ingria and the adjacent ones were traced in the paper:

(1) Evolution of the short second vowel in a (C) VCV(C) foot (kana): halflong opposed to long in the same position $\rightarrow(b)$ half-long only, and the second long durational type in the non-initial syllables $\left(\bar{V}_{2}>\grave{V}_{2}>\breve{V}_{2}\right) \rightarrow$ (c) the longest durational type in the non-initial syllables $\left({ }^{*} \grave{V}_{2}>{ }^{*} \bar{V}_{2}>{ }^{*} \breve{V}_{2}\right)$. (2) Evolution of the long second vowel in a (C)VCV(C) foot $(k a n \overline{\boldsymbol{a}})$ : (a) long opposed to half-long in the same position $\left(\overline{\mathbf{V}}_{2}>\grave{V}_{2}\right)>(b)$ disappearance of

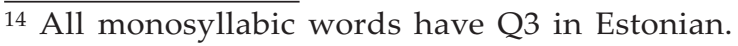


the contrast in this position in course of either merger with half-long $\left(\overline{\mathbf{V}}_{2}\right.$ $=\grave{V}_{2}$ ) or restructurization of the whole structure $(k a n \overline{\boldsymbol{a}}>$ kann $\overline{\boldsymbol{a}})$.

(3) Evolution of the non-initial long vowels in other positions (linn $\overline{\boldsymbol{a}}$ ): (a) the longest type in the non-initial syllables $\left(\overline{\mathbf{V}}_{2}>\grave{V}_{2}>\breve{V}_{2}\right) \rightarrow(b)$ second long type in the non-initial syllables $\left({ }^{*} \grave{V}_{2}>{ }^{*} \overline{\mathbf{V}}_{2}>{ }^{*} \breve{V}_{2}\right) \rightarrow(\mathrm{c})$ short vowel $\left(\grave{V}_{2}>{ }^{*} \overline{\mathbf{V}}_{2}=\mathrm{V}_{2}\right)$. (4) Evolution of the non-initial short vowels (linna) is summed up in Table 5. In the left column, the stages of reduction are briefly described. In the right column, the synchronic phonological system of non-initial short vowels that corresponds to each stage (or a series of stages) is given. The vocalic system at the first stage is the same as it is usually reconstructed for Proto-Finnic.

Table 5

Evolutionary stages of the non-initial short vowels, as indicated from the Finnic varieties discussed in the paper

\begin{tabular}{|c|c|c|c|c|c|}
\hline \multirow{4}{*}{$\begin{array}{l}\begin{array}{l}\text { Stages of reduction of etymological short non- } \\
\text { initial vowels }\end{array} \\
\text { (1) Short non-initial vowels in a robust length } \\
\text { contrast with long vowels (ratio } 1: 2.3-2.8 \text {; } \\
\text { the phonetic distance is even greater than for } \\
\text { the initial vowels: } \bar{V}_{2} / V_{2}>\bar{V}_{1} / V_{1} \text {; }\end{array}$} & \multicolumn{5}{|c|}{$\begin{array}{l}\text { Phonological system of non-initial short } \\
\text { vowels at each stage }\end{array}$} \\
\hline & & \multirow{6}{*}{$\begin{array}{l}\ddot{\mathrm{u}} \\
\ddot{\mathrm{o}} \\
\ddot{\mathrm{a}}\end{array}$} & \multirow{6}{*}{$\begin{array}{l}\mathrm{i} \\
\mathrm{e}\end{array}$} & \\
\hline & & & & o & \\
\hline & & & & $\mathrm{a}$ & \\
\hline \multicolumn{3}{|l|}{$\begin{array}{l}\text { (2) Shrinking of the phonetic distance } \\
\text { between short and long non-initial vowels } \\
\text { (ratio } 1: 1.2-1.7 \text { ); the distance between them } \\
\text { becomes smaller than between short and } \\
\text { long initial vowels: } \bar{V}_{2} / \bar{V}_{2}<\bar{V}_{1} / \breve{V}_{1} \text {; }\end{array}$} & & & \\
\hline \multicolumn{3}{|l|}{$\begin{array}{l}\text { (3) Occasional phonetic reduction of } a, \ddot{a}, e \\
\text { to schwa; regular grammatically conditioned } \\
\text { elision of vowels in certain morphemes; rare } \\
\text { phonetically conditioned elision of word-final } \\
\text { vowels; }\end{array}$} & & & \\
\hline \multicolumn{3}{|l|}{$\begin{array}{l}\text { (4) Regular phonetically conditioned elision } \\
\text { of all types of vowels in certain final and non- } \\
\text { final positions in a foot; }\end{array}$} & & & \\
\hline \multirow{2}{*}{$\begin{array}{l}\text { (5) The formation of the phonemic schwa out } \\
\text { of } a, \ddot{a} \text {, in some cases } e \text {; occasional phonetic } \\
\text { devoicing of reduced vowels; }\end{array}$} & $\ddot{\mathrm{u}}$ & $\mathrm{i}$ & & & $\mathrm{u}$ \\
\hline & $\ddot{\mathrm{o}}$ & e & ə $(<$ & $[\breve{a} / \breve{a} / \breve{e}])$ & \\
\hline \multirow{2}{*}{$\begin{array}{l}\text { (6) Frequent devoicing of reduced vowels; } \\
\text { a tendency to merge high and non-high } \\
\text { reduced vowels; reduced vowels form a } \\
\text { subsystem contrasted to the non-initial } \\
\text { short vowels; }\end{array}$} & $\breve{\text { u}}[\breve{u ̈}]$ & $\breve{1}[\breve{l}]$ & & & $\breve{\mathrm{u}}[\breve{u}]$ \\
\hline & ö́ $[\check{o ̈}]$ & e $[\breve{\varrho}]$ & 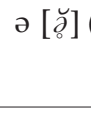 & $<[\breve{a} / \breve{a} / \breve{e}])$ & $\breve{o}[\breve{O}]$ \\
\hline $\begin{array}{l}\text { (7) Drastic increase in vowel elision; reduced } \\
\text { vowels lose the height contrast and are phono- } \\
\text { logically transformed into the consonantal } \\
\text { features of palatalization and labialization; }\end{array}$ & \multicolumn{2}{|c|}{$[t \stackrel{\mathrm{g}}{ }](<\mathrm{u} / \mathrm{o} / \mathrm{o})=\mathrm{t}^{\circ}$} & \multicolumn{3}{|c|}{$[t \breve{\partial}](<[\breve{a} / \breve{a} / \breve{e} / \breve{\imath}])=\mathrm{t}$} \\
\hline $\begin{array}{l}\text { (8) Loss of labialization; tendency to lose } \\
\text { palatalization. }\end{array}$ & \multicolumn{2}{|c|}{$\mathrm{t}^{\prime}\left(<\mathrm{t}^{\prime}, \mathrm{t}^{\prime \circ}\right)$} & \multicolumn{3}{|c|}{$\mathrm{t}\left(<\mathrm{t}, \mathrm{t}^{\circ}\right)$} \\
\hline
\end{tabular}

Finally, Table 6 presents the evolutionary path of the non-initial vocalic length contrast in general, summing up all the particular stages that were given separately in the end of each section. 
General evolutionary scheme of the non-initial vocalic length contrast, as indicated from the Finnic varieties discussed in the paper

\begin{tabular}{|c|c|c|c|}
\hline $\begin{array}{l}\text { *kana } \\
\text { 'hen:NOM' }\end{array}$ & $\begin{array}{l}\text { *kanā } \\
\text { 'hen:PRT' }\end{array}$ & $\begin{array}{l}\text { *linnā 'city/ } \\
\text { fortress:PRT' }\end{array}$ & $\begin{array}{l}\text { *linna 'city/, } \\
\text { fortress:NOM' }\end{array}$ \\
\hline \multirow[t]{4}{*}{ kana kanà $\mathrm{Fi}$} & kanā Fi & linnā $\mathrm{Fi}$ & linna $\mathrm{Fi}$ \\
\hline & $\downarrow$ & $\downarrow$ & $\downarrow$ \\
\hline & kanà kanā kan̆nò & linnà InS & linna $\sim$ linn \\
\hline & VoL (partly), InS & & (but loss in certain \\
\hline \multirow[t]{2}{*}{$\downarrow$} & & & $\begin{array}{l}\text { morphemes, e.g. } \\
{ }^{*} \text { naine }>\text { nain }\end{array}$ \\
\hline & $k$ & $\downarrow$ & $\begin{array}{l}\text { 'woman:NOM') } \\
\text { FiSK, FiI, InS } \\
\downarrow\end{array}$ \\
\hline \multirow{13}{*}{$\begin{array}{l}\text { kanà } \sim \text { kanā } \\
\text { FiSK, InS, InLL, } \\
\text { VoL, FiRyž, Es }\end{array}$} & & kannà = linnà & linna $\sim$ linnə $\sim$ lin̄ \\
\hline & & FiSK, FiI, & InNLL \\
\hline & & InNLL, InCLL, & \\
\hline & & VoL (partly) & \\
\hline & & $\downarrow$ & $\downarrow$ \\
\hline & & kanna $=$ linna & linnа $\sim \operatorname{li} \bar{n}$ \\
\hline & & InSLL, FiRyž & $\begin{array}{l}\text { InCLL, VoL } \\
\downarrow\end{array}$ \\
\hline & & & 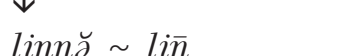 \\
\hline & & & (also e.g. püut't ${ }^{\prime} \ddot{u} \sim$ \\
\hline & & & $p^{\prime} \ddot{u ̈ t} t^{\prime \circ} \sim$ püt $^{\prime}$ \\
\hline & & & InSLL, FiRyž \\
\hline & & & $\downarrow$ \\
\hline & & & 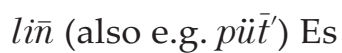 \\
\hline
\end{tabular}

\section{Acknowledgements}

This study is supported by the Grant of the President of Russian Federation for young PhDs, no. MK-4291.2015.6, and the Russian Foundation for Humanities, grant no. 13-04-00416. I am indebted to Tiit-Rein Viitso, Elena Markus and Matt Coler for their valuable comments.

\section{Address}

Natalia Kuznetsova

Institute for Linguistic Studies, Russian Academy of Sciences

E-mail: nkuzn@yandex.ru

\section{Abbreviations}

$2-2^{\text {nd }}$ person; $3-3^{\text {rd }}$ person; ACT - active; AD - adessive; ALL - allative; ILL illative; IMP - imperative; IN - inessive; IPS - impersonal; NMLZ - nominalization; NOM - nominative; PL - plural; PRS - non-past; PRT - partitive; PST - past; PC participle; SG - singular; TRL - translative.

Es - Standard Estonian; EsCN - Central North Estonian dialect; Fi - Standard Finnish; FiI - Ingrian Finnish; FiRyž - mixed Siberian Ingrian/Finnish variety of the Ryžkovo village; FiSK - South-Eastern Finnish dialects of Karelia; InCLL Central Lower Luga Ingrian; InLL - Lower Luga Ingrian; InNLL - North Lower Luga Ingrian; InS - Soikkola Ingrian; InSLL - South Lower Luga Ingrian; VoL Votic of the Luu(di)tsa village. 


\section{R E F E R E N C E S}

A r i s t e, P. 1953, Eesti keele foneetika, Tartu.

- - 1965, Etwas über das Ižorische. - СФУ I, 183-186.

- - 1968, A Grammar of the Votic Language, Bloomington-The Hague (UAS 68).

B 1 e vi n s, J. 2004, Evolutionary Phonology. The Emergence of Sound Patterns, Cambridge.

B y b e e, J. 2001, Phonology and Language Use, Cambridge (Cambridge Studies in Linguistics 94).

E e k, A. 1971, Articulation of the Estonian Sonorant Consonants III. Palatalized $[n]$ and $[m]$. - ETATÜS 20, 173-190.

- - 1973, Observations in Estonian Palatalization. An Articulatory Study. Estonian Papers in Phonetics, 18-36.

E e k, A., M e i s t e r, E. 2003, Foneetilisi katseid ja arutlusi kvantiteedi alalt I. - KK, 815-837, 904-918.

- - 2004, Foneetilisi katseid ja arutlusi kvantiteedi alalt II. - KK, 251-271, $337-357$.

G o r d o n, M. 1998, The Phonetics and Phonology of Non-Modal Vowels. A CrossLinguistic Perspective. - Berkeley Linguistics Society 24, 93-105.

H i n t, M. 1998, Häälikutest sõnadeni. Eesti keele häälikusüsteem üldkeeleteaduslikul taustal, Tallinn.

I i vo ne n, A., S ovijärvi, A., A u l a n k o R. 1990, Foneettisen kirjoituksen kehitys ja nykytila: kansainvälinen foneettinen aakkosto (IPA), suomalais-ugrilainen tarkekirjoitus (SUT), Helsinki (Helsingin yliopiston fonetiikan laitoksen monisteita 16).

K e t t u n e n, L. 1930, Suomen murteet II. Murrealueet, Helsinki (SKST 188).

K u z n e t s o v a, N, 2011, Typology of Prosodic Systems in Low Luga Izhorian Varieties. - Proceedings of Conference on Language Documentation and Linguistic Theory 2, London, 185-192.

- - 2012, Vowel Reduction in Lower Luga Ingrian. Scientific Description and "Folk" Perception. - 'Folk Linguistics'. Language from Speakers' Perspective. Paper Abstracts for the Conference, St. Petersburg, November 19-21, 2012, St. Petersburg, 85-87.

- - 2013, Finnic Foot Nucleus Lengthening. From Phonetics to Phonology. Nordic Prosody. Proceedings of the XIth Conference, Tartu, 2012, Frankfurt am Main, 205-214.

- - 2015, Two Phonological Rarities in Ingrian Dialects. - New Trends in Nordic and General Linguistics, Berlin (Linguae \& Litterae 42), 91-117.

K u z n e t s ova, N., F e d o t o v, M. 2013, Is There a Pure Quantitative Contrast of Non-Initial Vowels in Contemporary Votic? - Conference on Finnic Minority Languages and Cultures. Finnic Languages, Cultures and Genius Loci. Dedicated to Tiit-Rein Viitso's $75^{\text {th }}$ Birthday, Tartu, 66-68.

Kuznetsova, N., Markus, E., Mus 1 i m ov, M. 2015, Finnic Minorities of Ingria. The Current Sociolinguistic Situation and Its Background. Cultural and Linguistic Minorities in the Russian Federation and the European Union, Berlin (Multilingual Education 13. Comparative Studies on Equality and Diversity), 127-167.

$\mathrm{L}$ a a n e s t, A. 1980, Inkeroismurteiston suhteista suomen kaakkoismurteisiin. - Vir., 142-149.

- - 1984, Lõpukaost isuri keeles. - ESA 28 1982, 68-75.

L a u g a s t e, G. 1956, Konsonantide palatalisatsioon eesti keeles. - TRÜT 43, $74-85$.

L e h i s t e, I. 1960, Segmental and Syllabic Quantity in Estonian. - American Studies in Uralic Linguistics, Bloomington (UAS 1), $21-82$.

- - 1977, Isochrony Reconsidered. - Journal of Phonetics 5, 253-263.

L e h t o n e n, J. 1970, Aspects of Finnish Quantity, Jyväskylä.

L e s k i n e n, H. 1973, Kaakkoissuomalaisen loppuheiton yleisyydestä ja alkuperästä. - JSFOu 72, 210-221.

1978, Kaksi kaakkoismurteiden ja inkeroismurteiden kestoseikkaa. - Vir., $122-130$. 
L e s k i n e n, H., L e h t o n e n, J. 1973, Kvantiteettisuhteista läntisissä kaakkoismurteissa. - Vir., 315-326.

1985, Zur wortphonologischen Quantität in den Südostdialekten des Finnischen. - Ostseefinnische Untersuchungen. Ergebnisse eines finnisch-sowjetischen Symposions, Helsinki (Studia Fennica 28), 49-80.

M ä g i s t e, J. 1925, Rosona (Eesti Ingeri) murde pääjooned, Tartu (ACUT B, Humaniora, 7, 3).

M a r u s, E. 2010, Primary and Secondary Geminates in Ingrian. - LU XLVI, $38-52$.

- 2011, The Phonetics and Phonology of a Disyllabic Foot in Soikkola Ingrian. - LU XLVII, 103-119.

M e i s t e r, E., M e i s t e r, L. 2013, Native and Non-Native Production of Estonian Quantity Degrees. Comparison of Estonian, Finnish and Russian Subjects. - Nordic Prosody. Proceedings of the XIth Conference, Tartu, 2012, Frankfurt am Main, 235-244.

M u s t, M., U n i v e r e, A. 2002, Põhjaeesti keskmurre. Häälikulisi ja morfoloogilisi peajooni, Tallinn (Eesti Keele Instituudi toimetised 10).

N i r v i, R. E. 1972, Siperian inkeriläisten murteesta ja alkuperästä. - Kotiseutu 2/3, $92-95$.

O p e r s t e i n, N. 2010, Consonant Structure and Prevocalization, Amsterdam Philadelphia.

P a 1 a n d e r, M. 1987, Suomen itämurteiden erikoisgeminaatio, Helsinki-Jyväskylä (SKST 455).

P o s t i, L. 1980, Kukkosin murteesta ja sen asemasta. - L. P o s t i, S. S u h on e n, Vatjan kielen Kukkosin murteen sanakirja, Helsinki (LSFU 19), XV— XXI.

Prin ce, A. S. 1980, A Metrical Theory for Estonian Quantity. - Linguistic Inquiry $11,511-562$.

R o s c h, E. 1978, Principles of Categorization. - Cognition and Categorization, Hillsdale, 27-47.

R o z h a n s k i y, F. 2013, Vowel Length as Distinctive Feature of Case Forms in Votic. - Nordic Prosody. Proceedings of the XIth Conference, Tartu, 2012, Frankfurt am Main, 313-322.

- - 2015, The Length of the Final Vowels with Respect to Case Syncretism in Luuditsa Votic. - LU LI, 100-133.

S i d o r k e vich, D. V. 2011, On Domains of Adessive-Allative in Siberian Ingrian Finnish. - Acta Linguistica Petropolitana VII (3), 575-607.

S u o m i, K., M e i s t e r, E., Y 1 i t a l o, R., M e i s t e r, L. 2013, Durational Patterns in Northern Estonian and Northern Finnish. - Journal of Phonetics $41,1-16$.

Ta u li, V. 1953-1954, The Origin of the Quantitative System in Estonian. JSFOu 57, $1-19$.

- - 1956, Phonological Tendencies in Estonian, Copenhagen (Det Kongelige Danske Videnskabernes Selskab. Historisk-filologiske Meddelelser 36 (1)).

Te r a s, P., P a j u s a 1 u, K. 2014, Palatalisatsioonist ja prepalatalisatsioonist spontaanses eesti keeles. - KK, 257-269.

V i i t s o, T.-R. 1961, Vadja Luutsa-Liivčülä murraku fonoloogia. - ESA VII 1961, $142-174$.

- - 1964, Hilisgeminatsioonist vadja keeles. - Töid läänemeresoome ja volga keelte alalt, Tallinn, 24-35.

_ - 2008, Liivi keel ja läänemeresoome keelemaastikud, Tartu - Tallinn.

W i i k, K. 1975, On Vowel Duration in Finnish Dialects. - CIFU III, 415-424.

- - 1991, On a Third Type of Speech Rhythm. Foot timing. - Proceedings of the XIIth International Congress of Phonetic Sciences, August 19-24, 1991, Aix-en-Provence. Pars 3, Aix-en-Provence, 298-299.

W i i k, K., L e h i s t e, I. 1968, Vowel Quantity in Finnish Disyllabic Words. - CIFU II, 569-574.

Z 1 o b i n a, V. 1972, Mitä alkujuurta Siperian suomalaiset ja korlakat ovat. Kotiseutu 2/3, 86-92.

3 л о б и н а В. 1971, Кто такие корлаки? - СФУ VII, 87-91. 
К а с а т к и н Л. Л. 1999, Современная русская диалектная и литературная фонетика как источник для истории русского языка, Москва.

К у 3 н е ц о в а Н. В. 2009а, Супрасегментная фонетика сойкинского диалекта ижорского языка в типологическом аспекте. - ВЯ, № 5, 18-47.

- - 2009b, Фонологические системы ижорских диалектов. Диссертация на соискание ученой степени кандидата филологических наук, Санкт-Петербург.

- - 2012, Просодика словоформы в нижнелужском диалекте ижорского языка. - Acta Linguistica Petropolitana VIII (1), 43-103.

Л а а н е с т А. 1966, Ижорские диалекты. Лингвогеографическое исследование, Таллин.

М у с л и м о в М. 3. 2005, Языковые контакты в Западной Ингерманландии (нижнее течение реки Луги). Диссертация на соискание ученой степени кандидата филологических наук, Санкт-Петербург.

- - 2009, К классификации финских диалектов Ингерманландии. - Вопросы уралистики 2009. Научный альманах, Санкт-Петербург, 179-204.

П о п о в М. Б. 2004, Проблемы синхронической и диахронической фонологии русского языка, Санкт-Петербург.

С и д о р к е в и ч Д. В. 2012, Ингерманландцы в Сибири: этническая идентичность в многоэтничном окружении. - Acta Linguistica Petropolitana VIII (1), 194-285.

- - 2013а, Фонологическая система сибирского ингерманландского идиома. - Acta Linguistica Petropolitana IX (2), 657-702.

- - 2013b, Язык ингерманландских переселенцев XIX в. в Сибири (структуpa, диалектные особенности, контактные явления). Диссертация на соискание ученой степени кандидата филологических наук, Санкт-Петербург.

\section{НАТАЛЬЯ КУЗНЕЦОВА (Санкт-Петербург)}

\section{ПУТЬ РАЗВИТИЯ КОЛИЧЕСТВЕННОЙ ОППОЗИЦИИ НЕНАЧАЛЬНЫХ ГЛАСНЫХ В ПРИБАЛТИЙСКО-ФИНСКИХ ЯЗЫКАХ И ГОВОРАХ ИНГЕРМАНЛАНДИИ И СОПРЕДЕЛЬНЫХ ТЕРРИТОРИЙ}

В живых вариантах финского языка (Ингерманландии, Сибири, Южной Карелии, Финляндии), а также ижорского, водского, эстонского языков представлены последовательные этапы процесса редукции неначальных гласных. Схема звукового перехода здесь может быть смоделирована достаточно точно и поэтапно, с привлечением статистических фонетических данных для каждого этапа. В частности, описаны изменения различных типов пропорциональных отношений между долгими и краткими гласными от наиболее консервативного этапа, представленного в литературном финском, к более инновационным идиомам. Отдельно представлен фонетический эксперимент по речепроизводству кратких гласных в южных говорах нижнелужского диалекта ижорского языка и контактном ижорско-финском сибирском ингерманландском идиоме, где их редукция, оглушение и падение зашли особенно далеко. Также приведены коррелирующие данные эксперимента по фонемной категоризации рефлексов кратких гласных самими носителями этих идиомов. Результаты обоих экспериментов указывают на то, что в первом идиоме эти рефлексы еще сохраняют фонологический статус гласных, а во втором их следует уже трактовать как дополнительные признаки согласных: палатализацию и лабиализацию. 